\title{
Estimation of GFR in children using rescaled beta-trace protein
}

\author{
Emil den Bakker ${ }^{\mathrm{a}}$, Reinoud Gemke ${ }^{\mathrm{a}}$, Hans Pottel ${ }^{\mathrm{b}}$, Joanna A.E. van Wijk ${ }^{\mathrm{a}}$, Isabelle Hubeek ${ }^{\mathrm{c}}$, \\ Birgit Stoffel-Wagner ${ }^{\mathrm{d}}$, Arend Bökenkamp ${ }^{\mathrm{a}, *}$ \\ a Department of Pediatrics, Amsterdam University Medical Center, Amsterdam, The Netherlands \\ ${ }^{\mathrm{b}}$ Department of Public Health and Primary Care, KU Leuven, Kortrijk, Belgium \\ c Department of Clinical Chemistry, Amsterdam University Medical Center, Amsterdam, The Netherlands \\ d Department of Clinical Chemistry and Clinical Pharmacology, University Clinics, Bonn, Germany
}

\section{A B S T R A C T}

Introduction: Beta-trace protein (BTP) is a low molecular weight protein, pro-

duced mainly in the cerebrospinal fluid. It has been proposed as a marker for kidney function. Recently, a new method for GFR estimation using mean normal values to rescale GFR marker concentrations has been described for creatinine and cystatin C, two commonly used endogenous markers for kidney function. The aim of this study is to apply this approach to BTP in children.

Method: We retrospectively analyzed serum concentrations of creatinine, cystatin C and BTP measured during inulin clearance tests in children. BTP was measured using a particle-enhanced immunonephelometric assay (Siemens Healthcare). A novel BTP-based eGFR equation was developed using published normal values for children: $\mathrm{eGFR}_{\mathrm{BTP}}\left[\mathrm{ml} / \mathrm{min} / 1.73 \mathrm{~m}^{2}\right]=107.3 / \mathrm{BTP} / \mathrm{Q}_{\mathrm{BTP}}$ with $\mathrm{Q}_{\mathrm{BTP}}=0.69$. Performance of this equation was compared to the established creatinine-based full age spectrum equation FASage and the cystatin C-based FAScys equations as well as the BTP-based Benlamri equation in terms of bias, \% prediction error and $\mathrm{P}_{30}$ and $\mathrm{P}_{10}$ accuracy rates.

Results: 322 inulin clearance tests were studied. Overall, our novel equation performed comparably to the creatinine-based FASage and the BTP-based Benlamri equations but was less accurate than FAScys $\left(\mathrm{P}_{30}: 79.2\right.$ vs $\left.86.3 \%, p=.008\right)$. Combining markers significantly enhanced performance compared to the single marker equations, with the exception of FAScys.

Conclusion: Rescaled BTP concentrations are a simple method for estimating GFR in children. However, the additional value of BTP for the estimation of GFR compared to rescaled creatinine and cystatin C still remains to be demonstrated.

\section{Introduction}

Beta-trace protein (BTP) is a low molecular weight protein (molecular weight ranging from 20 to $31 \mathrm{kDa}$ ) with a carbohydrate residue on the N-terminal end accounting for the large variance in molecular weight [1]. It is produced primarily in the central nervous system by glial cells, leptomeningeal cells and in the choroid plexus [2,3]. Therefore, highest concentrations are found in cerebrospinal fluid $[4,5]$. BTP leaks from the cerebrospinal fluid into the serum, where significantly lower concentrations are observed [6]. The liver eliminates BTP with shorter residues, resulting in distinct cerebrospinal fluid and serum glycosylation patterns. Therefore, serum BTP has a higher molecular weight and the weight distribution is narrower (26-29 kDa) [6-8]. Like other low-molecular weight proteins, serum BTP is almost exclusively eliminated through glomerular filtration and degraded in the proximal tubules [9]. Therefore serum BTP has been proposed as a marker of GFR in both children and adults [10-12].

In order to convert serum levels of an endogenous GFR marker to an estimate of GFR, marker-specific eGFR equations are required [13]. Usually, these equations are calculated using some form of linear regression analysis [11,14-16]. A major disadvantage of this method is that unknown confounding factors in the calibrating population will alter the slope of the regression [13]. Moreover, in order to create an equation that is applicable over the full spectrum of GFR, subjects comprising the whole range of GFR must be present in the population, including patients with very low GFR. Many of such patients have severe co-morbidity, adding to the impact of unknown confounding factors. The distribution of GFR in a nephrology unit usually peaks at CKD stages 3 to 4 and fewer patients with mildly impaired or more advanced renal failure are included in the large cohorts used to create the most widespread current eGFR equations (CKD-EPI, mean GFR $70 \mathrm{ml} / \mathrm{min}$ / $1.73 \mathrm{~m}^{2}$ [17]; MDRD, $40 \mathrm{ml} / \mathrm{min} / 1.73 \mathrm{~m}^{2}$ [18]; CKiD, $43 \mathrm{ml} / \mathrm{min}$ / $1.73 \mathrm{~m}^{2}[15]$.

Recently, Pottel et al. [19] developed an alternative strategy to create eGFR equations by using appropriate normal values to rescale the marker concentration in an individual patient. These normal values

\footnotetext{
* Corresponding author at: Department of Pediatric Nephrology, Amsterdam University Medical Center, De Boelelaan 1118, NL-1081 HV Amsterdam, The Netherlands.

E-mail address: a.bokenkamp@vumc.nl (A. Bökenkamp).
} 
are derived from healthy populations where GFR is normal. Due to changes in muscle mass during growth and development, creatinine reference values change rapidly and separate gender-specific reference values $\left(Q_{\text {crea }}\right)$ are needed $[19,20]$. This is not the case for cystatin C, where age, height or sex have no [13] or only mild [21] effects in the pediatric age range, resulting in a constant reference range and thus a single $Q$ value [22].

Rescaling serum levels to individual reference values has several advantages [23]. (i) It makes the different markers easier to compare. While serum creatinine levels differ from serum cystatin $C$ levels, rescaled creatinine levels and rescaled cystatin $C$ levels should be very similar. (ii) Rescaled serum markers follow a normal distribution with a mean of 1 . Therefore, the further the rescaled marker deviates from 1 , the further the eGFR will be from normal. (iii) Since differences in age, height or sex are incorporated in the $Q$ values, the rescaled serum levels are independent of these factors, and the resulting equations can be used across the full age spectrum.

The eGFR equations following this approach have been shown to perform well in diverse pediatric populations [19,22,24-26]. For BTP, a similar approach yielded results in elderly patients suggesting that a FASBTP equation would perform similarly [27].

The aim of this study is to apply this method in children and develop an eGFR equation using rescaled serum concentrations of BTP, which can be incorporated in an equation for the full age spectrum (FAS) and compare this equation to existing eGFR equations.

\section{Methods}

\subsection{Data collection}

Retrospective analysis was carried out in 322 inulin plasma clearance tests (Cin) performed in 322 children on clinical grounds over a period of 11 years. During the clearance study, blood had been taken for the measurement of serum creatinine, cystatin C and BTP. Height, weight and primary diagnosis were extracted from the patient charts, as was use of glucocorticosteroids.

Inulin clearance was measured by intravenous administration of $5000 \mathrm{mg} / 1.73 \mathrm{~m}^{2}$ body surface of inulin (Inutest ${ }^{\circledR}$, Fresenius, Bad Homburg, Germany) with a maximum of $5000 \mathrm{mg}$. Subsequently, serum samples were taken 10, 30, 90 and $240 \mathrm{~min}$ after injection and inulin concentrations measured using an enzymatic method [28]. Clearance was calculated from the decline in serum concentration using MW/Pharm 3.5 software (Mediware, Groningen, The Netherlands), a pharmacokinetic computer program using a Bayesian estimate from patient and population data [29]. This method has been described previously in more detail [24].

Between March 2008 and September 2014 creatinine was measured using an IDMS traceable creatinase/sarcosine oxidase enzymatic method on the Modular P800 chemistry analyzer (Roche Diagnostics, Mannheim, Germany) [30]. The intraassay coefficient of variation for creatinine was $0.7 \%$ (mean $=1.21 \mathrm{umol} / \mathrm{L}, n=10)$, whereas the interassay coefficient of variation (CV) was $1.8 \%$ (mean $=368 \mathrm{umol} / \mathrm{l}$; $\mathrm{n}=10$ ). Creatinine results from September 2014 onwards were measured using the same IDMS traceable assay on the Cobas8000 chemistry analyzer (Roche Diagnostics, Mannheim, Germany; interassay $\mathrm{CV}=1.5 \%$, mean $80 \mathrm{umol} / 1$ and 1.4\%, mean $593 \mathrm{umol} / 1$ (Unity Real Time QC, Biorad). For measurements before 2008, a kinetic Jaffe reaction was used (Modular P800, Roche Diagnostics, Mannheim, Germany). These measurements were corrected to fit IDMS traceability by an equation developed locally [IFCC creatinine $(\mu \mathrm{mol} / \mathrm{l})=$ Jaffe creatinine $\times 1.1-26]$.

Both serum cystatin C and serum BTP levels were measured using particle enhanced immunonephelometric assays (N Latex CYSC ${ }^{\mathrm{TM}}$ and $\mathrm{N}$ Latex BTP ${ }^{\mathrm{TM}}$, Siemens Healthcare Diagnostics, Eschborn, Germany) on a Behring Nephelometer II. For cystatin C the assay was calibrated to fit IFCC reference material (ERM ${ }^{\oplus}$-DA471/IFCC). For data collected prior to the use of this reference material from 2013 onwards, a conversion factor of 1.17 was used as recommended by the manufacturer. The intraassay coefficient of variation for BTP was $2.8 \%$ (mean $=1.6 \mathrm{mg} / \mathrm{l}$; $n=10$ ), whereas the interassay coefficient of variation was $3.7 \%$ (mean $=1.7 \mathrm{mg} / \mathrm{l} ; n=10$ ). The intraassay coefficient of variation for cystatin $\mathrm{C}$ was $2.9 \%$ (mean $=1.1 \mathrm{mg} / \mathrm{l} ; \mathrm{n}=10$ ), whereas the interassay coefficient of variation was $3.4 \%$ (mean $=1.3 \mathrm{mg} / \mathrm{l} ; \mathrm{n}=10$ ).

\subsection{Characteristics of BTP in a subset with normal renal function}

From our database, a subset of unique patients was selected to estimate the normal BTP concentration and assess the influence of age, height, weight, BMI and sex on the serum levels of BTP. In order to qualify for inclusion in this dataset measured GFR had to be above $90 \mathrm{ml} / \mathrm{min} / 1.73 \mathrm{~m}^{2}$. Exclusion criteria were active malignancy, nephritis, glucocorticoid use and neural tube defects.

\subsection{Development and evaluation of a BTP-based eGFR equation}

The BTP-based eGFR equation was constructed using the mean BTP concentration found in healthy children from a different population where BTP had been measured in the same laboratory with the same nephelometric assay [2]. In analogy to the FAScys and FAScrea [23] the equation for $\mathrm{eGFR}_{\mathrm{BTP}}$ was:

(i) eGFR $_{\text {BTP }}\left[\mathrm{ml} / \mathrm{min} / 1.73 \mathrm{~m}^{2}\right]=107.3\left[\mathrm{ml} / \mathrm{min} / 1.73 \mathrm{~m}^{2}\right] / \mathrm{S}_{\text {BTP }} / \mathrm{Q}_{\text {BTP }}$

with $S_{\text {BTP }}$ in $\mathrm{mg} / \mathrm{l}$ and $\mathrm{Q}_{\mathrm{BTP}} ; 0.69 \mathrm{mg} / \mathrm{l}$

The performance of this new equation was compared to the BTPbased equation described by Benlamri et al. [31].

(ii) eGFR $_{\text {Benlamri }}\left[\mathrm{ml} / \mathrm{min} / 1.73 \mathrm{~m}^{2}\right]=10^{(1.902+(0.9515 \times \log (1 / \mathrm{BTP})))}$

with BTP in mg/las well as the creatinine-based full age spectrum FAScrea equation [19].

(iii) FAScrea $\left[\mathrm{ml} / \mathrm{min} / 1.73 \mathrm{~m}^{2}\right]=107.3\left[\mathrm{ml} / \mathrm{min} / 1.73 \mathrm{~m}^{2}\right] / \mathrm{Scr} / \mathrm{Q}_{\text {crea }}$

with Scr in $\mathrm{mg} / \mathrm{dl}$ and $\mathrm{Q}_{\text {crea }}$ being the age-related normal value of creatinine in $\mathrm{mg} / \mathrm{dland}$ the cystatin C-based full age spectrum (FAScys) Eq. [22].

(iv) FAScys $\left[\mathrm{ml} / \mathrm{min} / 1.73 \mathrm{~m}^{2}\right]=107.3\left[\mathrm{ml} / \mathrm{min} / 1.73 \mathrm{~m}^{2}\right] / \mathrm{Scys} / \mathrm{Q}_{\text {cys }}$

with Scys in $\mathrm{mg} / \mathrm{l}$ and $\mathrm{Q}_{\text {cys }} ; 0.82 \mathrm{mg} / \mathrm{l}$ being the normal value of cystatin C.

Finally, we also compared the individual equations to the arithmetic [i.e. $\left(\mathrm{eGFR}_{\mathrm{a}}+\mathrm{eGFR} \mathrm{b}\right) / 2$ ] and geometric [i.e. $\left(\mathrm{eGFR}_{\mathrm{a}} \times \mathrm{eGFR}_{\mathrm{b}}\right)^{0.5}$ ] means calculated from eGFR $\mathrm{BTP}_{\mathrm{BT}}$, FAScrea and/or FAScys.

The performance in terms of \%prediction error and $\mathrm{P}_{30}$ and $\mathrm{P}_{10}$ accuracy were compared across diagnosis groups, levels of measured GFR, glucocorticosteroid (GCS) use,sex and age. For levels of measured GFR, we also calculated the percentage of cases in which the eGFR equation correctly identified the CKD level (\% correctly identified CKD).

\subsection{Statistical analysis}

We used the following parameters to explore performance of the different eGFR equations. (i) Bias was defined as eGFR - Cin (ii) $\%$ prediction error as $100 \times($ eGFR-Cin)/Cin in \%, absolute \%prediction error as $100 \times(\mid$ Cin-eGFR $\mid) /$ Cin in $\%$. $\mathrm{P}_{30}$ and $\mathrm{P}_{10}$ accuracy describe the percentage of cases where eGFR was within $\pm 30 \%$ or $\pm 10 \%$ of Cin.

Continuous variables were analyzed using Spearman's correlation. For the dichotomous variable sex, an independent samples $t$-test was 
Table 1

Patient characteristics of the healthy subgroup and the total dataset. Data are given as median [interquartile range] or as percentage.

\begin{tabular}{|c|c|c|c|}
\hline & & Healthy subgroup & Total dataset \\
\hline \multicolumn{2}{|l|}{ Number } & 91 & 322 \\
\hline \multicolumn{2}{|c|}{ GFR $\left(\mathrm{ml} / \mathrm{min} / 1.73 \mathrm{~m}^{2}\right)$} & $\begin{array}{l}100.0 \text { [94.1 to } \\
110.7]\end{array}$ & $\begin{array}{l}94.3[76.7 \text { to } \\
109.8]\end{array}$ \\
\hline \multicolumn{2}{|l|}{ \%males } & $54.9 \%$ & $59 \%$ \\
\hline \multicolumn{2}{|c|}{ Height (m) } & $\begin{array}{l}164.0 \text { [141.4 to } \\
175.0]\end{array}$ & $\begin{array}{l}158.0 \text { [133.9 to } \\
171.5]\end{array}$ \\
\hline \multicolumn{2}{|c|}{ Weight (kg) } & $56.5[35.0$ to 69.0$]$ & $50.5[30.9$ to 64.0$]$ \\
\hline \multicolumn{2}{|c|}{ BMI $\left(\mathrm{kg} / \mathrm{m}^{2}\right)$} & 20.2 [16.9 to 23.2$]$ & $19.2[16.7$ to 22.4$]$ \\
\hline \multicolumn{2}{|c|}{ Age (years) } & 15.5 [10.8 to 17.7$]$ & 14.2 [9.4 to 17.4$]$ \\
\hline \multicolumn{2}{|c|}{ Serum creatinine $(\mathrm{mg} / \mathrm{dl})$} & $0.69[0.52$ to 0.86$]$ & $0.69[0.48$ to 0.91$]$ \\
\hline \multicolumn{2}{|c|}{ Serum cystatin C (mg/l) } & $0.96[0.84$ to 1.03$]$ & $1.01[0.87$ to 1.22$]$ \\
\hline \multicolumn{2}{|c|}{ Serum BTP (mg/l) } & $0.73[0.64$ to 0.82$]$ & 0.77 [0.65 to 0.99$]$ \\
\hline \multirow[t]{7}{*}{ Diagnosis } & Malignancy & $0 \%$ & $19.6 \%$ \\
\hline & Single kidney & $52.7 \%$ & $28.6 \%$ \\
\hline & Nephritis & $0 \%$ & $14.0 \%$ \\
\hline & Urological & $15.4 \%$ & $10.9 \%$ \\
\hline & Spina bifida & $0 \%$ & $9.0 \%$ \\
\hline & $\begin{array}{l}\text { Follow-up after } \\
\text { malignancy }\end{array}$ & $6.6 \%$ & $4.0 \%$ \\
\hline & Other & $25.3 \%$ & $14.0 \%$ \\
\hline
\end{tabular}

used. Accuracy rates were compared using McNemar tests.

\section{Results}

\subsection{Population characteristics}

Over a period of 11 years, 322 inulin clearance tests with simultaneous BTP and creatinine serum levels were documented in 322 unique patients. Patient age ranged from 2.1 to 19.5 years with a median of 14.2 years, median GFR measured by inulin clearance was $94.3 \mathrm{ml}$ / $\mathrm{min} / 1.73 \mathrm{~m}^{2}$ with a range from 13.4 to $185.0 \mathrm{ml} / \mathrm{min} / 1.73 \mathrm{~m}^{2}$. Further characteristics are summarized in Table 1.

Of the 322 measurements, 91 cases fit the inclusion criteria for the group with normal renal function. Here, median age was 15.5 years (range 2.3 to 19.5), $54.9 \%$ were male, median GFR was $100.0 \mathrm{ml} / \mathrm{min}$ / $1.73 \mathrm{~m}^{2}$ and median serum BTP levels was $0.730 \mathrm{mg} / \mathrm{l}$. Further characteristics of this group with normal renal function are summarized in Table 1.

None of the factors studied with Pearson's correlation had a significant effect on BTP concentrations (Table 2). However gender did have a significant effect on BTP concentrations (median $0.745 \mathrm{mg} / 1$ in males vs $0.690 \mathrm{mg} / \mathrm{l}$ in females, $p=.025$ ).

We used median BTP concentrations in this analysis, since the data in our healthy subgroup group were not normally distributed (Fig. 1; Shapiro-Wilk test for normality $0.813, p=.000$ ), furthermore due to the relatively small reference group, outliers would have more impact on the mean.

\section{2. eGFR equation}

We tested the new eGFR $\mathrm{BTP}_{\mathrm{BT}}$ equation in terms of bias, \%prediction error, $\mid \%$ prediction error $\mid$ and $\mathrm{P}_{30}$ and $\mathrm{P}_{10}$ accuracy rates (Table 3 ).

Table 2

Factors potentially related to the serum concentrations of BTP in the healthy subgroup.

\begin{tabular}{ll}
\hline & Spearman's correlation (p-value) \\
\hline Age & $-0.165(p=.119)$ \\
Height & $-0.098(p=.357)$ \\
Weight & $-0.122(p=.249)$ \\
BMI & $-0.122(\mathrm{p}=.249)$ \\
\hline
\end{tabular}

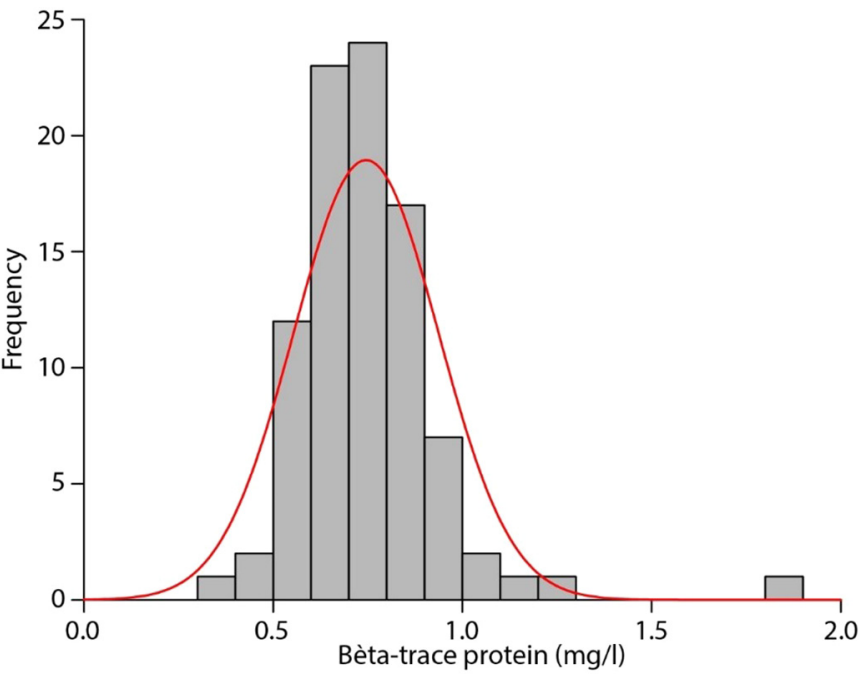

Fig. 1. Distribution of serum levels of BTP in our healthy subgroup.

Overall, eGFR $\mathrm{BTP}_{\mathrm{BT}}$ performed comparably to the creatinine-based FASage and the BTP-based Benlamri equations and was significantly less accurate than FAScys $\left(\mathrm{P}_{30}: 79.2\right.$ vs $\left.86.3 \%, p=.008\right)$. Combining equations as geometric or arithmetic mean led to improvement in all outcome parameters. The combination of all three performed best with significantly higher $\mathrm{P}_{30}$ and $\mathrm{P}_{10}$ accuracy rates compared to any of the three single marker equations, with the exception of FAScys, for which the increased accuracy did not reach statistical significance. Combining all three markers did not improve accuracy when compared to pairs of any two of the eGFR equations.

Analyzing different categories of measured GFR (Table 4), performance of eGFR $_{\mathrm{BTP}}$, and the Benlamri equation declined progressively with decreasing GFR, while accuracy of FAScrea and FAScys was comparable in CKD 1 and CKD 2. Performance of FAScys at GFR < $60 \mathrm{ml} / \mathrm{min} / 1.73 \mathrm{~m}^{2}$ tended to be higher than FAScrea and Benlamri, but this did not reach statistical significance due to small numbers in this subgroup. This was also reflected in the more consistent percentages in which the correct CKD group was identified for patients using the FAScys equation.

The performance of the equations in different diagnosis groups is presented in Table 5. Here, FAScys clearly outperformed the other equations in patients with spina bifida, with exceedingly low accuracy for FAScrea. Of note, both BTP-based eGFR equations also performed less accurately in this group compared to all other diagnoses and share a negative bias. There were no significant differences in performance between the eGFR equations in the other diagnosis groups. Prediction was most accurate in patients with a single kidney.

Considering the effect of glucocorticosteroids (Table 6), we observed a decrease in accuracy but similar \%precision error with FAScrea, while both eGFR $\mathrm{BTP}_{\mathrm{BT}}$, and FAScys performed less accurately and shifted towards a negative bias in patients on GCS therapy.

When examining differences between males and females, both BTP equations showed a clear decrease in accuracy in adolescent (12 years or older) females, while FAScrea showed a decrease in accuracy for females in younger children.

\section{Discussion}

This study demonstrates that rescaled BTP can be used for GFR estimation in children, using the same principle as described for creatinine [19] and cystatin C [22]. It is in line with a recent study using this approach with BTP in elderly patients [27]. The resulting equation performs similarly to the creatinine-based FAScrea and the BTP-based Benlamri equation. As in the adult study, addition of more markers 
Table 3

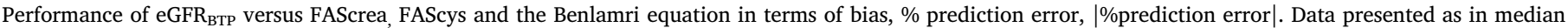
[interquartile range] $\mathrm{ml} / \mathrm{min} / 1.73 \mathrm{~m}^{2}$. Accuracy presented as $\mathrm{P}_{30}$ and $\mathrm{P}_{10}$ in $\%$.

\begin{tabular}{|c|c|c|c|c|c|}
\hline & Bias & $\%$ prediction error & $\mid \%$ prediction error| & $\mathrm{P}_{30}$ accuracy & $\mathrm{P}_{10}$ accuracy \\
\hline Benlamri & $5.8[-5.5$ to 22.1$]$ & $7.1[-6.2$ to 25.0$]$ & $14.4[6.5$ to 28.0$]$ & 78.0 & 37.6 \\
\hline eGFR $\mathrm{BTP}_{\mathrm{B}}$ & $-0.2[-11.2$ to 15.8$]$ & $-0.2[-12.3$ to 18.1$]$ & 15.0 [6.9 to 25.5$]$ & 79.2 & 33.9 \\
\hline FAScys & $-5.1[-17.2$ to 4.3$]$ & $-4.8[-17.5$ to 6.2$]$ & $13.7[5.3$ to 22.4$]$ & 86.3 & 40.7 \\
\hline FAScrea & $3.8[-6.2$ to 16.9$]$ & 4.8 [ -9.8 to 21.3$]$ & 13.9 [6.7 to 24.7$]$ & 80.4 & 35.1 \\
\hline \multicolumn{6}{|c|}{ Arithmetic means } \\
\hline eGFR $_{\text {BTP-crea }}$ & $2.7[-5.9$ to 14.1$]$ & $3.1[-7.5$ to 18.0$]$ & 11.7 [5.1 to 22.9$]$ & 82.6 & 45.0 \\
\hline eGFR BTP_cys & $-1.6[-11.7$ to 8.4$]$ & $-1.9[-13.5$ to 10.4$]$ & 12.0 [4.7 to 21.6$]$ & 87.0 & 41.9 \\
\hline eGFR crea_cys & $-0.8[-9.7$ to 9.6$]$ & $-0.9[-9.9$ to 13.4$]$ & 11.3 [4.6 to 19.5$]$ & 87.3 & 47.2 \\
\hline eGFR BTP_cys_crea & $0.3[-8.7$ to 11.3$]$ & $0.3[-9.3$ to 13.5$]$ & 11.0 [5.4 to 20.7] & 87.6 & 45.0 \\
\hline \multicolumn{6}{|l|}{ Geometric means } \\
\hline eGFR BTP_crea $_{\text {B }}$ & $2.1[-6.4$ to 13.3$]$ & $2.4[-8.3$ to 16.8$]$ & 11.5 [5.2 to 22.4$]$ & 83.5 & 45.0 \\
\hline eGFR BTP_cys & $-1.8[-12.6$ to 7.8$]$ & $-2.3[-13.7$ to 9.8$]$ & 12.0 [4.5 to 21.3$]$ & 86.7 & 42.9 \\
\hline $\mathrm{eGFR}_{\text {crea_cys }}$ & $-1.1[-10.6$ to 9.0$]$ & $-1.2[-10.7$ to 13.0$]$ & $11.6[4.7$ to 19.7$]$ & 88.8 & 45.3 \\
\hline eGFR BTP_cys_crea & $-0.1[-9.8$ to 9.5$]$ & $-0.2[-10.2$ to 12.1$]$ & $10.7[5.6$ to 20.0$]$ & 87.9 & 46.0 \\
\hline
\end{tabular}

Table 4

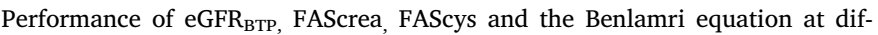
ferent levels of GFR $\left[\mathrm{ml} / \mathrm{min} / 1.73 \mathrm{~m}^{2}\right]$ in terms of \%prediction error presented as median [interquartile range] and $\mathrm{P}_{30}$ and $\mathrm{P}_{10}$ accuracy in $\%$ as well as their ability to correctly identify CKD level in \%.

\begin{tabular}{|c|c|c|c|c|}
\hline GFR & & $\geq 90$ & $60-89$ & $\leq 59$ \\
\hline $\mathrm{N}$ & & 188 & 94 & 40 \\
\hline \multirow[t]{4}{*}{ Benlamri } & $\begin{array}{l}\text { \%prediction error } \\
{[I Q R]}\end{array}$ & $\begin{array}{l}3.1[-10.7 \text { to } \\
18.1]\end{array}$ & $\begin{array}{l}14.7[-0.5 \\
\text { to } 37.9]\end{array}$ & $\begin{array}{l}11.6[-4.8 \text { to } \\
41.6]\end{array}$ \\
\hline & P30 & 84.0 & 73.4 & 60.0 \\
\hline & P10 & 37.8 & 38.3 & 35.0 \\
\hline & $\begin{array}{l}\text { \%correctly } \\
\text { identified CKD }\end{array}$ & 86.2 & 43.6 & 67.5 \\
\hline \multirow[t]{4}{*}{ eGFR ${ }_{\text {BTP }}$} & $\begin{array}{l}\text { \%prediction error } \\
{[I Q R]}\end{array}$ & $\begin{array}{l}-3.0[-16.0 \\
\text { to } 12.7]\end{array}$ & $\begin{array}{l}7.3[-7.7 \\
\text { to } 28.7]\end{array}$ & $\begin{array}{l}-1.7[-16.5 \text { to } \\
30.3]\end{array}$ \\
\hline & P30 & 85.1 & 73.4 & 65.0 \\
\hline & $P 10$ & 33.0 & 38.3 & 27.5 \\
\hline & $\begin{array}{l}\text { \%correctly } \\
\text { identified CKD }\end{array}$ & 79.3 & 53.1 & 70.0 \\
\hline \multirow[t]{4}{*}{ FAScys } & $\begin{array}{l}\text { \%prediction error } \\
{[I Q R]}\end{array}$ & $\begin{array}{l}-11.8[-22.0 \\
\text { to }-0.2]\end{array}$ & $\begin{array}{l}1.6[-9.6 \\
\text { to } 11.3]\end{array}$ & $\begin{array}{l}9.4[-3.0 \text { to } \\
25.8]\end{array}$ \\
\hline & P30 & 86.7 & 88.3 & 80.0 \\
\hline & P10 & 37.8 & 51.1 & 30.0 \\
\hline & $\begin{array}{l}\text { \%correctly } \\
\text { identified CKD }\end{array}$ & 64.9 & 69.1 & 82.5 \\
\hline \multirow[t]{4}{*}{ FAScrea } & $\begin{array}{l}\text { \%prediction error } \\
{[I Q R]}\end{array}$ & $\begin{array}{l}1.0[-12.1 \text { to } \\
16.3]\end{array}$ & $\begin{array}{l}10.0[-1.3 \\
\text { to } 21.8]\end{array}$ & $\begin{array}{l}11.8[-12.1 \text { to } \\
33.2]\end{array}$ \\
\hline & P30 & 82.5 & 83.0 & 65.0 \\
\hline & P10 & 36.7 & 38.3 & 20.0 \\
\hline & $\begin{array}{l}\text { \%correctly } \\
\text { identified } C K D\end{array}$ & 80.9 & 53.2 & 70.0 \\
\hline
\end{tabular}

enhanced the performance of the equations, albeit to a lesser extent. It is therefore a matter of debate whether the slight increase in accuracy is worth the extra cost of measuring a third marker. However, since the equations are based on rescaled markers, there is great potential for combining or interchanging different markers depending on specific patient characteristics.

The poorer performance of both cystatin C and BTP in patients on GCS treatment is in line with earlier reports [32,33], and is most marked for FAScys. This is remarkable as GCS had a stronger effect on BTP in our previous study [32], where BTP concentrations were inversely correlated with GCS dose. Bias of FAScrea was not affected by GCS treatment, which is consistent with earlier reports [34]. The poor performance of creatinine in the group with neural tube defects follows reason as these patients are known to have diminished muscle mass. Both eGFR $_{\mathrm{BTP}}$ and the Benlamri equation overestimate GFR in spina bifida patients and are less suitable than FAScys in this patient group as described previously [35]. The underlying pathophysiology for this observation is unclear.

Analysis of the subgroup with normal GFR revealed a median measured GFR of $100 \mathrm{ml} / \mathrm{min} / 1.73 \mathrm{~m}^{2}$, which is lower than the normal value of $107.3 \mathrm{ml} / \mathrm{min} / 1.73 \mathrm{~m}^{2}$ Pottel used for the calculation of the rescaled eGFR equations $[19,22,36]$. This may reflect differences in patient population. In order to conform to his concept and to yield comparable data with FAScys and FAScrea, we used $107.3 \mathrm{ml} / \mathrm{min} /$ $1.73 \mathrm{~m}^{2}$ in our eGFR $\mathrm{BTP}_{\mathrm{BT}}$ equation.

Differences between our population and the population used for the definition of $\mathrm{Q}_{\text {ВтP }}$ probably also account for the lower median GFR in our patients with normal GFR and the patients from the earlier cohort [2], which was used for the definition of $Q_{\text {Bтр. }}$ In the latter, mean Schwartz-GFR was $108 \mathrm{ml} / \mathrm{min} / 1.73 \mathrm{~m}^{2}$. This may explain why the Qvalue of $0.69 \mathrm{mg} / \mathrm{l}$ is lower than the median concentration of $0.73 \mathrm{mg} / 1$ observed in our subgroup with normal kidney function. Here, too, we chose not to adapt the $\mathrm{Q}_{\text {втр }}$ value to the findings in our population in order to avoid a bias favoring the in-house eGFR $\mathrm{BTP}_{\mathrm{BT}}$ equation.

We observed significantly higher serum levels of BTP in boys, which have also been reported by a number of other studies $[11,27,31,37]$ but not in our earlier publication and in the study by Filler et al. [38]. Considering our Table 7, it is quite possible that the difference in gender does not arise until adolescent age, i.e. cohorts with younger children will not report gender related differences, whereas cohorts with older children will. Of note, the Benlamri equation, which was developed in children at median age of 11 years, also does not differentiate for gender.

There have been no reports indicating an association between age or height and BTP concentrations. Still, we observed a trend towards an inverse relation with BTP concentrations and age and height. This may be the reason why Pottel found a lower $Q_{\text {втр }}$ of $0.60 \mathrm{mg} / 1$ in elderly subjects [27]. This indicates that a potential BTP equation covering the full age spectrum might require age-specific $Q$ values. Filler et al. reported that thyroid function might alter BTP concentrations [38]. This was not addressed in the present study.

Our study has several limitations. (i) The Q-value was adapted from a group of children without known kidney disease [2]. GFR had not been measured in these children, however. Also, the children were younger $(10.4 \pm 4.6$ years) than the patients in the present study. This may account for the differences in median BTP concentration in the patients with normal kidney function and the Q-value used in our equation. Still, eGFR $\mathrm{BTP}_{\mathrm{BP}}$ performs very well in our population and had remarkably low bias. Possibly, the Q-value can be adapted in a larger study, optimally covering the whole age spectrum. It is conceivable that such a study will come up with gender-specific Q-values from adolescence (ii) Our patients were relatively old for a pediatric population. This has to be borne in mind when extrapolating our findings to a 
Table 5

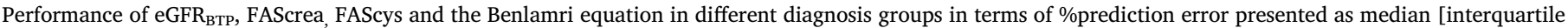
range] and $\mathrm{P}_{30}$ and $\mathrm{P}_{10}$ accuracy in \%.

\begin{tabular}{|c|c|c|c|c|c|c|c|c|}
\hline Diagnosis & & Malignancy & Nephritis & Single kidney & Spina bifida & $\begin{array}{l}\text { Follow up after } \\
\text { malignancy }\end{array}$ & Urological & Other \\
\hline $\mathrm{N}$ & & 63 & 45 & 92 & 29 & 13 & 35 & 45 \\
\hline \multirow[t]{3}{*}{ Benlamri } & $\begin{array}{l}\text { \%prediction error } \\
{[I Q R]}\end{array}$ & $2.3[-11.8$ to 16.1$]$ & $\begin{array}{l}2.0[-12.1 \text { to } \\
18.8]\end{array}$ & $\begin{array}{l}9.0[-3.8 \text { to } \\
25.2]\end{array}$ & $\begin{array}{l}28.5 \text { [2.6 to } \\
51.5]\end{array}$ & $8.3[-1.0$ to 31.4$]$ & $\begin{array}{l}-0.1[-5.8 \text { to } \\
16.7]\end{array}$ & $8.5[-5.1$ to 23.2$]$ \\
\hline & P30 & 81.0 & 75.6 & 82.6 & 55.2 & 76.9 & 77.1 & 82.2 \\
\hline & P10 & 36.5 & 42.2 & 39.1 & 17.2 & 46.2 & 51.4 & 31.1 \\
\hline \multirow[t]{3}{*}{ eGFR ${ }_{\text {BTP }}$} & $\begin{array}{l}\text { \%prediction error } \\
{[I Q R]}\end{array}$ & $\begin{array}{l}-3.7[-17.3 \text { to } \\
10.3]\end{array}$ & $\begin{array}{l}-4.5[-19.1 \text { to } \\
13.2]\end{array}$ & $\begin{array}{l}2.5[-9.5 \text { to } \\
18.5]\end{array}$ & $\begin{array}{l}20.9[-3.7 \text { to } \\
45.9]\end{array}$ & $-0.0[-7.6$ to 24.5$]$ & $\begin{array}{l}-8.2[-16.2 \text { to } \\
10.3]\end{array}$ & $0.9[-12.5$ to 17.0$]$ \\
\hline & P30 & 82.5 & 80.0 & 84.8 & 62.1 & 76.9 & 77.1 & 75.6 \\
\hline & P10 & 36.5 & 31.1 & 37.0 & 24.1 & 53.9 & 28.6 & 31.1 \\
\hline \multirow[t]{3}{*}{ FAScys } & $\begin{array}{l}\text { \%prediction error } \\
{[I Q R]}\end{array}$ & $\begin{array}{l}-13.2[-24.5 \text { to } \\
1.9]\end{array}$ & $\begin{array}{l}-15.0[-24.0 \text { to } \\
0.8]\end{array}$ & $\begin{array}{l}-3.1[-13.3 \\
\text { to } 6.1]\end{array}$ & $\begin{array}{l}1.0[-12.4 \text { to } \\
17.5]\end{array}$ & $1.0[-5.4$ to 9.3$]$ & $\begin{array}{l}-3.0[-16.5 \text { to } \\
4.0]\end{array}$ & $\begin{array}{l}-2.1[-16.3 \text { to } \\
11.2]\end{array}$ \\
\hline & P30 & 77.8 & 77.8 & 93.5 & 89.7 & 92.3 & 88.6 & 86.7 \\
\hline & $P 10$ & 34.9 & 24.4 & 53.3 & 44.8 & 61.5 & 34.3 & 35.6 \\
\hline \multirow[t]{3}{*}{ FAScrea } & $\begin{array}{l}\text { \%prediction error } \\
{[I Q R]}\end{array}$ & $6.3[-10.7$ to 28.7$]$ & $\begin{array}{l}3.7[-12.2 \text { to } \\
18.9]\end{array}$ & $\begin{array}{l}1.9[-9.9 \text { to } \\
17.5]\end{array}$ & $\begin{array}{l}40.9 \text { [10.8 to } \\
90.8]\end{array}$ & $7.6[-3.0$ to 34.1$]$ & $\begin{array}{l}-3.1[-14.3 \text { to } \\
8.9]\end{array}$ & $6.4[-7.4$ to 16.4$]$ \\
\hline & P30 & 74.6 & 82.2 & 89.1 & 44.8 & 69.2 & 94.3 & 84.4 \\
\hline & $P 10$ & 34.9 & 28.9 & 39.1 & 13.8 & 46.2 & 42.9 & 37.8 \\
\hline
\end{tabular}

Table 6

Performance of eGFR $_{\mathrm{BTP}}$, FAScrea, FAScys and the Benlamri equation split by glucocorticosteroid use in terms of \%prediction error presented as median [interquartile range] and $\mathrm{P}_{30}$ and $\mathrm{P}_{10}$ accuracy in \%.

\begin{tabular}{|c|c|c|c|}
\hline Steroids & & Yes & No \\
\hline $\mathrm{N}$ & & 37 & 285 \\
\hline \multirow[t]{3}{*}{ Benlamri } & $\begin{array}{l}\% \text { prediction error } \\
{[I Q R]}\end{array}$ & 0.7 [ -12.9 to 22.6$]$ & $7.5[-5.9$ to 25.1$]$ \\
\hline & $P_{30}$ & 70.3 & 79.0 \\
\hline & $P_{10}$ & 37.8 & 37.5 \\
\hline \multirow[t]{3}{*}{$\mathrm{eGFR}_{\mathrm{BTP}}$} & $\begin{array}{l}\% \text { prediction error } \\
{[I Q R]}\end{array}$ & $\begin{array}{l}-4.5[-18.0 \text { to } \\
14.8]\end{array}$ & $0.2[-12.0$ to 18.2$]$ \\
\hline & $P_{30}$ & 75.7 & 79.7 \\
\hline & $P_{10}$ & 27.0 & 34.7 \\
\hline \multirow[t]{3}{*}{ FAScys } & $\begin{array}{l}\% \text { prediction error } \\
{[I Q R]}\end{array}$ & $\begin{array}{l}-23.5[-30.8 \text { to } \\
-12.3]\end{array}$ & $-3.1[-15.5$ to 7.0$]$ \\
\hline & $P_{30}$ & 70.3 & 88.4 \\
\hline & $P_{10}$ & 13.5 & 44.2 \\
\hline \multirow[t]{3}{*}{ FAScrea } & $\begin{array}{l}\% \text { prediction error } \\
{[I Q R]}\end{array}$ & $3.7[-12.8$ to 23.9$]$ & $4.8[-9.1$ to 20.6$]$ \\
\hline & $P_{30}$ & 73.0 & 81.4 \\
\hline & $P_{10}$ & 27.0 & 36.1 \\
\hline
\end{tabular}

general pediatric population. (iii) Unlike for creatinine and cystatin $\mathrm{C}$ [39-41] no international reference standard for BTP measurement has been established to date. In the past, differences in assay standardization were a major obstacle for the implementation of cystatin $\mathrm{C}$ in clinical practice [37]. Therefore, caution is warranted when extrapolating the results from this study to populations where a different assay for BTP measurement is used.

\section{Conclusion}

Rescaled BTP concentrations are a simple method for estimating GFR in children. However, in our cohort, they provided little additional benefit over rescaled creatinine and cystatin C. In the future, this method might be used to develop an equation covering the full age spectrum from pediatrics to old age.

\section{Conflicts of interest}

None.
Table 7

Performance of eGFR ${ }_{\text {BTP, }}$ FAScrea FAScys and the Benlamri equation split by age and sex in terms of \%prediction error presented as median [interquartile range] and $\mathrm{P}_{30}$ and $\mathrm{P}_{10}$ accuracy in \%.

\begin{tabular}{|c|c|c|c|c|c|}
\hline \multirow{2}{*}{$\begin{array}{l}\text { Age } \\
\text { Sex }\end{array}$} & & \multicolumn{2}{|l|}{ Children } & \multicolumn{2}{|l|}{ Adolecents } \\
\hline & & Male & Female & Male & Female \\
\hline $\mathrm{N}$ & & 70 & 60 & 120 & 72 \\
\hline \multirow[t]{3}{*}{ Benlamri } & $\begin{array}{l}\% \text { prediction } \\
\text { error }[I Q R]\end{array}$ & $\begin{array}{l}-0.3 \\
{[-12.3 \text { to }} \\
15.7]\end{array}$ & $\begin{array}{l}8.7[-5.3 \\
\text { to } 26.7]\end{array}$ & $\begin{array}{l}4.6[-6.5 \\
\text { to } 19.6]\end{array}$ & $\begin{array}{l}22.0 \text { [ } 1.2 \text { to } \\
39.2]\end{array}$ \\
\hline & $P_{30}$ & 81.4 & 80.0 & 80.8 & 68.1 \\
\hline & $P_{10}$ & 35.7 & 35.0 & 42.5 & 33.3 \\
\hline \multirow[t]{3}{*}{$\mathrm{eGFR}_{\mathrm{BTP}}$} & $\begin{array}{l}\text { \% prediction } \\
\text { error }[I Q R]\end{array}$ & $\begin{array}{l}-7.0 \\
{[-18.5 \text { to }} \\
9.3]\end{array}$ & $\begin{array}{l}2.3 \\
{[-11.5 \text { to }} \\
20.4]\end{array}$ & $\begin{array}{l}-1.9 \\
{[-13.4 \text { to }} \\
12.6]\end{array}$ & $\begin{array}{l}15.0[-5.2 \\
\text { to } 31.2]\end{array}$ \\
\hline & $P_{30}$ & 82.9 & 80.0 & 81.7 & 70.8 \\
\hline & $P_{10}$ & 34.3 & 33.3 & 39.2 & 25.0 \\
\hline \multirow[t]{3}{*}{ FAScys } & $\begin{array}{l}\% \text { prediction } \\
\text { error }[I Q R]\end{array}$ & $\begin{array}{l}-6.1 \\
{[-19.9 \text { to }} \\
2.1]\end{array}$ & $\begin{array}{l}-2.5 \\
{[-12.0 \text { to }} \\
6.8]\end{array}$ & $\begin{array}{l}-10.9 \\
{[-19.8 \text { to }} \\
2.0]\end{array}$ & $\begin{array}{l}2.5[-13.2 \\
\text { to } 16.5]\end{array}$ \\
\hline & $P_{30}$ & 87.1 & 83.3 & 90.8 & 80.6 \\
\hline & $P_{10}$ & 41.3 & 55.0 & 36.7 & 34.7 \\
\hline \multirow[t]{3}{*}{ FAScrea } & $\begin{array}{l}\text { \% prediction } \\
\text { error }[I Q R]\end{array}$ & $\begin{array}{l}1.1 \\
{[-14.0 \text { to }} \\
16.5]\end{array}$ & $\begin{array}{l}9.1[-8.9 \\
\text { to } 35.7]\end{array}$ & $\begin{array}{l}3.9[-9.0 \\
\text { to } 18.6]\end{array}$ & $\begin{array}{l}9.0[-7.9 \text { to } \\
23.2]\end{array}$ \\
\hline & $P_{30}$ & 85.7 & 66.7 & 82.5 & 83.3 \\
\hline & $P_{10}$ & 38.6 & 28.3 & 39.2 & 30.6 \\
\hline
\end{tabular}

\section{References}

[1] Y. Urade, O. Hayaishi, Biochemical, structural, genetic, physiological, and pathophysiological features of lipocalin-type prostaglandin D synthase, Biochim. Biophys. Acta 1482 (1-2) (2000) 259-271.

[2] A. Bokenkamp, I. Franke, M. Schlieber, G. Duker, J. Schmitt, S. Buderus, M.J. Lentze, B. Stoffel-Wagner, Beta-trace protein-a marker of kidney function in children: "original research communication-clinical investigation", Clin. Biochem. 40 (13-14) (2007) 969-975.

[3] Y. Ohe, K. Ishikawa, Z. Itoh, K. Tatemoto, Cultured leptomeningeal cells secrete cerebrospinal fluid proteins, J. Neurochem. 67 (3) (1996) 964-971.

[4] E. Arrer, C. Meco, G. Oberascher, W. Piotrowski, K. Albegger, W. Patsch, beta-Trace protein as a marker for cerebrospinal fluid rhinorrhea, Clin. Chem. 48 (6 Pt 1) (2002) 939-941.

[5] N. van der Wielen, Q. Gemke, R. Rinkel, R. Gemke, Failure to thrive related to nasal encephalocele in a toddler: a diagnostic challenge, J. Pediatr. Neurol. (2016) 039-042.

[6] J.E. Olsson, H. Link, B. Nosslin, Metabolic studies on 125I-labelled beta-trace protein, with special reference to synthesis within the central nervous system, J. Neurochem. 21 (5) (1973) 1153-1159. 
[7] A. Hoffmann, M. Nimtz, H.S. Conradt, Molecular characterization of beta-trace protein in human serum and urine: a potential diagnostic marker for renal diseases, Glycobiology 7 (4) (1997) 499-506.

[8] C.A. White, S. Ghazan-Shahi, M.A. Adams, $\beta$-Trace protein: a marker of GFR and other biological pathways, Am. J. Kidney Dis. 65 (1) (2015) 131-146.

[9] C. Donadio, L. Bozzoli, Urinary $\beta$-trace protein: a unique biomarker to screen early glomerular filtration rate impairment, Medicine (Baltimore) 95 (49) (2016) e5553.

[10] C. Donadio, A. Lucchesi, M. Ardini, E. Donadio, R. Giordani, Serum levels of betatrace protein and glomerular filtration rate-preliminary results, J. Pharm. Biomed. Anal. 32 (4-5) (2003) 1099-1104.

[11] S.H. Witzel, S.H. Huang, B. Braam, G. Filler, Estimation of GFR using $\beta$-trace protein in children, Clin. J. Am. Soc. Nephrol. 10 (3) (2015) 401-409.

[12] L.A. Inker, H. Tighiouart, J. Coresh, M.C. Foster, A.H. Anderson, G.J. Beck, G. Contreras, T. Greene, A.B. Karger, J.W. Kusek, J. Lash, J. Lewis, J.R. Schelling, S.D. Navaneethan, J. Sondheimer, T. Shafi, A.S. Levey, GFR estimation using $\beta$-trace protein and B2-microglobulin in CKD, Am. J. Kidney Dis. 67 (1) (2016) 40-48.

[13] E. den Bakker, R.J.B.J. Gemke, A. Bökenkamp, Endogenous markers for kidney function in children: a review, Crit. Rev. Clin. Lab. Sci. (2018) 1-21.

[14] G.J. Schwartz, G.B. Haycock, C.M. Edelmann, A. Spitzer, A simple estimate of glomerular filtration rate in children derived from body length and plasma creatinine, Pediatrics 58 (2) (1976) 259-263.

[15] G.J. Schwartz, M.F. Schneider, P.S. Maier, M. Moxey-Mims, V.R. Dharnidharka, B.A. Warady, S.L. Furth, A. Munoz, Improved equations estimating GFR in children with chronic kidney disease using an immunonephelometric determination of cystatin C, Kidney Int. 82 (4) (2012) 445-453.

[16] U.B. Berg, U. Nyman, R. Bäck, M. Hansson, K. Monemi, M. Herthelius, J. Björk, New standardized cystatin C and creatinine GFR equations in children validated with inulin clearance, Pediatr. Nephrol. 30 (8) (2015) 1317-1326.

[17] L.A. Inker, C.H. Schmid, H. Tighiouart, J.H. Eckfeldt, H.I. Feldman, T. Greene, J.W. Kusek, J. Manzi, F. Van Lente, Y.L. Zhang, J. Coresh, A.S. Levey, C.E. Investigators, Estimating glomerular filtration rate from serum creatinine and cystatin C, N. Engl. J. Med. 367 (1) (2012) 20-29.

[18] A.S. Levey, J. Coresh, T. Greene, L.A. Stevens, Y.L. Zhang, S. Hendriksen, J.W. Kusek, F. Van LenteC.K.D.E. Collaboration, Using standardized serum creatinine values in the modification of diet in renal disease study equation for estimating glomerular filtration rate, Ann. Intern. Med. 145 (4) (2006) 247-254.

[19] H. Pottel, L. Hoste, L. Dubourg, N. Ebert, E. Schaeffner, B.O. Eriksen, T. Melsom, E.J. Lamb, A.D. Rule, S.T. Turner, R.J. Glassock, V. De Souza, L. Selistre, C. Mariat, F. Martens, P. Delanaye, An estimated glomerular filtration rate equation for the full age spectrum, Nephrol. Dial. Transplant. 31 (5) (2016) 798-806.

[20] H. Pottel, N. Vrydags, B. Mahieu, E. Vandewynckele, K. Croes, F. Martens, Establishing age/sex related serum creatinine reference intervals from hospital laboratory data based on different statistical methods, Clin. Chim. Acta 396 (1-2) (2008) 49-55.

[21] D. Groesbeck, A. Köttgen, R. Parekh, E. Selvin, G.J. Schwartz, J. Coresh, S. Furth, Age, gender, and race effects on cystatin C levels in US adolescents, Clin. J. Am. Soc. Nephrol. 3 (6) (2008) 1777-1785.

[22] H. Pottel, P. Delanaye, E. Schaeffner, L. Dubourg, B.O. Eriksen, T. Melsom, E.J. Lamb, A.D. Rule, S.T. Turner, R.J. Glassock, V. De Souza, L. Selistre, K. Goffin, S. Pauwels, C. Mariat, M. Flamant, N. Ebert, Estimating glomerular filtration rate for the full age spectrum from serum creatinine and cystatin C, Nephrol. Dial. Transplant. 32 (3) (2017) 497-507.

[23] H. Pottel, L. Dubourg, E. Schaeffner, B.O. Eriksen, T. Melsom, E.J. Lamb, A.D. Rule, S.T. Turner, R.J. Glassock, V. De Souza, L. Selistre, K. Goffin, S. Pauwels, C. Mariat, M. Flamant, S. Bevc, P. Delanaye, N. Ebert, The diagnostic value of rescaled renal biomarkers serum creatinine and serum cystatin $\mathrm{C}$ and their relation with measured glomerular filtration rate, Clin. Chim. Acta 471 (2017) 164-170.

[24] H.N. Blufpand, R. Westland, J.A. van Wijk, E.A. Roelandse-Koop, G.J. Kaspers,
A. Bökenkamp, Height-independent estimation of glomerular filtration rate in children: an alternative to the Schwartz equation, J. Pediatr. 163 (6) (2013) 1722-1727.

[25] E. den Bakker, R. Gemke, J.A.E. van Wijk, I. Hubeek, B. Stoffel-Wagner, A. Grubb, A. Bökenkamp, Accurate eGFR reporting for children without anthropometric data, Clin. Chim. Acta 474 (2017) 38-43.

[26] F. Leion, J. Hegbrant, E. den Bakker, M. Jonsson, M. Abrahamson, U. Nyman, J. Björk, V. Lindström, A. Larsson, A. Bökenkamp, A. Grubb, Estimating glomerular filtration rate (GFR) in children. The average between a cystatin C- and a creatininebased equation improves estimation of GFR in both children and adults and enables diagnosing Shrunken Pore Syndrome, Scand. J. Clin. Lab. Invest. (2017) 1-7.

[27] H. Pottel, E. Schaeffner, N. Ebert, Evaluating the diagnostic value of rescaled $\beta$-trace protein in combination with serum creatinine and serum cystatin $C$ in older adults, Clin. Chim. Acta 480 (2018) 206-213.

[28] C.P. Degenaar, L.A.M. Frenken, J.P. von Hooff, Enzymatic method for the determination of inulin, Clin. Chem. 33 (1987) 1070-1071.

[29] L.K. van Rossum, R.A. Mathot, K. Cransberg, A.G. Vulto, Optimal sampling strategies to assess inulin clearance in children by the inulin single-injection method, Clin. Chem. 49 (7) (2003) 1170-1179.

[30] M. Suzuki, M. Yoshida, A new enzymatic serum creatinine measurement based on an endogenous creatine-eliminating system, Clin. Chim. Acta 143 (2) (1984) $147-155$.

[31] A. Benlamri, R. Nadarajah, A. Yasin, N. Lepage, A.P. Sharma, G. Filler, Development of a beta-trace protein based formula for estimation of glomerular filtration rate, Pediatr. Nephrol. 25 (3) (2010) 485-490.

[32] A. Bokenkamp, C.A. Laarman, K.I. Braam, J.A. van Wijk, W.A. Kors, M. Kool, J. de Valk, A.A. Bouman, M.D. Spreeuwenberg, B. Stoffel-Wagner, Effect of corticosteroid therapy on low-molecular weight protein markers of kidney function, Clin. Chem. 53 (12) (2007) 2219-2221.

[33] F.C. Abbink, C.A. Laarman, K.I. Braam, J.A. van Wijk, W.A. Kors, A.A. Bouman, M.D. Spreeuwenberg, B. Stoffel-Wagner, A. Bokenkamp, Beta-trace protein is not superior to cystatin C for the estimation of GFR in patients receiving corticosteroids, Clin. Biochem. 41 (4-5) (2008) 299-305.

[34] E. den Bakker, B. Koene, J.A.E. van Wijk, I. Hubeek, R. Gemke, A. Bökenkamp, GFRestimation by serum creatinine during glucocorticosteroid therapy, Clin. Exp. Nephrol. (2018), https://doi.org/10.1007/s10157-018-1570-6 (ahead of print).

[35] A. Pham-Huy, M. Leonard, N. Lepage, J. Halton, G. Filler, Measuring glomerular filtration rate with cystatin $\mathrm{C}$ and beta-trace protein in children with spina bifida, $\mathrm{J}$. Urol. 169 (6) (2003) 2312-2315.

[36] H. Pottel, L. Hoste, F. Martens, A simple height-independent equation for estimating glomerular filtration rate in children, Pediatr. Nephrol. 27 (6) (2012) 973-979.

[37] C.A. White, A. Akbari, S. Doucette, D. Fergusson, N. Hussain, L. Dinh, G. Filler, N. Lepage, G.A. Knoll, A novel equation to estimate glomerular filtration rate using beta-trace protein, Clin. Chem. 53 (11) (2007) 1965-1968.

[38] G. Filler, C. Kusserow, L. Lopes, M. Kobrzyński, Beta-trace protein as a marker of GFR-history, indications, and future research, Clin. Biochem. 47 (13-14) (2014) 1188-1194.

[39] A. Grubb, S. Blirup-Jensen, V. Lindström, C. Schmidt, H. Althaus, I. Zegers, I.W.G.o.S.o.C.C. (WG-SCC), First certified reference material for cystatin C in human serum ERM-DA471/IFCC, Clin. Chem. Lab. Med. 48 (11) (2010) 1619-1621.

[40] M. Panteghini, Enzymatic assays for creatinine: time for action, Scand. J. Clin. Lab. Invest. 241 (2008) 84-88.

[41] G.L. Myers, W.G. Miller, J. Coresh, J. Fleming, N. Greenberg, T. Greene, T. Hostetter, A.S. Levey, M. Panteghini, M. Welch, J.H. Eckfeldt, N.K.D.E.P.L.W. Group, Recommendations for improving serum creatinine measurement: a report from the Laboratory Working Group of the National Kidney Disease Education Program, Clin. Chem. 52 (1) (2006) 5-18. 